\title{
Proteolytic enzyme activity in the gut of doe-suckled and hand-reared rabbits
}

\author{
By M. J. HENSCHEL \\ National Institute for Research in Dairying, Shinfield, Reading $R G 2{ }_{9} A T$
}

(Received 27 November 1972-Accepted 2 March 1973)

\begin{abstract}
1. Proteolytic activity in the stomachs and pancreases of infant doe- and hand-reared rabbits was studied to the age of $3-4$ weeks.

2. In the stomachs of both the doe- and hand-fed animals total proteolytic activity at birth was low, rising slowly during the first 2 weeks and then rapidly, until at 3 weeks of age the level was similar to that of the adult.

3. In the pancreases of the doe-suckled pups the level of proteolytic activity was highest during the ist week of life, falling steadily after that to a minimum at 3 weeks of age. In contrast in the hand-reared rabbits, it fell sharply during the ist week and then rose, reaching at 2 weeks of age a level slightly higher than that found in the doe-suckled pups.

4. Growth and survival of hand-reared rabbits during the first $12 \mathrm{~d}$ of life were improved by predigestion of the diet with trypsin and $\alpha$-chymotrypsin.
\end{abstract}

Over the past decade a high death rate has been observed in this laboratory among infant rabbits hand-reared on cow's milk in both conventional and germ-free conditions. The deaths, which have involved about two-thirds of the total number of rabbits, take place during the first 4 or 5 weeks post partum, and fall into one of two categories. In the first, which accounts for about four-fifths of the deaths and occurs up to $\mathrm{I} 2 \mathrm{~d}$ after birth, death is preceded by a steady decline in condition and a very poor growth rate. In the second, the animals that die often do so after a violent 'shock' reaction which occurs during or immediately after feeding. Coates \& O'Donoghue (1967) suggested that this reaction might be caused by allergy to a dietary protein.

The present paper is concerned with deaths in the first category only. The signs exhibited by the rabbits before death strongly resembled those of malnutrition, and it was suspected that the diet, already deficient in fat as compared with rabbit's milk, might not be adequately utilized by the rabbit pup. Studies were made of the ability of the neonatal rabbit to digest protein. The development of both the gastric and the pancreatic proteases in doe-suckled and hand-reared rabbits was studied during the first 3 or 4 weeks of life.

\section{EXPERIMENTAL}

Animals. The rabbits were bred from pure New Zealand White stock. The doesuckled rabbits were left with the does until killed. The hand-fed animals were either removed from the does as soon after birth as practicable and reared conventionally in a controlled-temperature room, or delivered by hysterectomy into a large Gustafsson isolator and reared germ-free. The temperature of both environments on reception of the pups was $37^{\circ}$, lowered by an average of $0.5^{\circ} \%$ to $27^{\circ}$ at $20 \mathrm{~d}$ of age when weaning began. 
Table I. Composition of standard rabbit artificial milk

$\begin{array}{lc}\text { Freeze-dried milk protein } & 62.5 \mathrm{~g} \\ \text { Vitamin supplement* } & \text { 10 } \mathrm{g} \\ \text { Raw whole cow's milk to } & \text { I } 1\end{array}$

* After Coates, Gregory \& Thompson (r964). r g contained: calcium pantothenate 4 mg, nicotinic acid I $\mathrm{mg}$, pyridoxine hydrochloride $0.4 \mathrm{mg}$, thiamin hydrochloride $0.2 \mathrm{mg}$, riboflavin $0.2 \mathrm{mg}$, pteroylmonoglutamic acid $25 \mu \mathrm{g}$, biotin $25 \mu \mathrm{g}$, cyanocobalamin $10 \mu \mathrm{g}$, Rovimix At (containing I $5 \mathrm{mg}$ retinol/g) $4 \mathrm{mg}$, Rovimix $\mathrm{D}_{3}$ roof (containing $2.5 \mathrm{mg}$ cholecalciferol/g) I $\mathrm{mg}$, glucose $0.99 \mathrm{~g}$.

† Roche Products Ltd, I5 Manchester Square, London W I.

Table 2. Proximate analysis of rabbit diet and of colostrum and mature milk of New Zealand White does

\begin{tabular}{|c|c|c|c|c|c|}
\hline \multirow[b]{2}{*}{ Diet } & \multirow{2}{*}{$\begin{array}{l}\text { Fat } \\
(g / 1)\end{array}$} & \multirow{2}{*}{$\begin{array}{c}\text { Protein } \\
(\mathrm{g} / \mathrm{l})\end{array}$} & \multirow{2}{*}{$\begin{array}{l}\text { Carbo- } \\
\text { hydrate } \\
\text { (gil) }\end{array}$} & \multicolumn{2}{|c|}{ Energy value } \\
\hline & & & & $\mathrm{kJ} / 1$ & kcal/l \\
\hline Rabbit diet & 32 & 95 & 48 & 3600 & 860 \\
\hline Does' colostrum, day I ${ }^{*}$ & 320 & I 45 & 7 & 14590 & $348 \%$ \\
\hline Does' colostrum, day $2^{*}$ & 260 & I30 & I9 & 13040 & 3 I 16 \\
\hline Does' milk* & 150 & $\mathrm{I} 40$ & 20 & 8330 & I 990 \\
\hline
\end{tabular}

Pups were killed with diethyl ether at weekly intervals from birth to 3 or 4 weeks of age; four of the conventional hand-reared rabbits were killed at $3 \mathrm{~d}$ of age. The groups of doe-suckled pups at each age contained at least six animals from four different litters; those of the hand-reared rabbits contained four from three litters. For additional pancreatic protease measurements only, individual members of three germ-free litters were killed, respectively, at birth, 3 and $7 \mathrm{~d}$; at birth, 7 and $14 \mathrm{~d}$; and at birth, 3, 7, I I, I3 and I $5 \mathrm{~d}$. For comparison, two adult rabbits were used. They were killed by a blow to the back of the head.

Diet. The standard diet consisted of raw cow's milk to which was added freezedried protein previously separated from skim milk on columns of Sephadex G-50 coarse, and a vitamin supplement. The composition of the diet is given in Table $\mathrm{I}$. The proximate analysis of the diet is compared with that of doe's colostrum and milk in Table 2 . The diet was sterilized in bulk by an indirect ultra high temperature (UHT) process and bottled aseptically in $500 \mathrm{ml}$ screw-topped bottles. The fat content of the diet was not increased over that of the whole milk, since any such addition before sterilization caused a serious blockage in the UH'T plant, and the subsequent addition of different lipids resulted in severe scouring by the rabbits.

The predigested diet was prepared as necessary by treating $500 \mathrm{ml}$ standard milk with $50 \mathrm{mg}$ each of crystalline trypsin and $\alpha$-chymotrypsin (Koch-Light Laboratories Ltd, Colnbrook, Bucks.) which had been sterilized by irradiation at $5.0 \mathrm{Mrad}$. This mixture was incubated aseptically at $30-37^{\circ}$ for at least $24 \mathrm{~h}$.

Feeding with enzyme-treated diet. Survival and growth in thirty-nine rabbits fed from birth on the diet predigested with trypsin and $\alpha$-chymotrypsin were compared with thirty-six control animals given the untreated diet. 
Table 3. Mean daily intakes of suckling Blue Vienna pups during the first $8 d$ of lactation and of eleven New Zealand White hand-fed rabbits given the standard diet

\begin{tabular}{|c|c|c|c|c|c|c|c|c|}
\hline \multirow{3}{*}{$\begin{array}{l}\text { Age } \\
\text { (d) }\end{array}$} & \multicolumn{4}{|c|}{ Doe-suckled } & \multicolumn{4}{|c|}{ Hand-reared } \\
\hline & \multicolumn{2}{|c|}{ Dietary intake* $(\mathrm{g})$} & \multicolumn{2}{|c|}{ Energy intake } & \multicolumn{2}{|c|}{ Dietary intake $(g)$} & \multicolumn{2}{|c|}{ Energy intake } \\
\hline & Mean & $\mathrm{SE}$ & $\mathrm{kJ}$ & kcal & Mean & SE & $\mathrm{kJ}$ & kcal \\
\hline I & $5 \cdot 53$ & 0.37 & $80 \cdot 7$ & $19 \cdot 3$ & $14 * 18$ & 0.85 & $5 \mathrm{I} \cdot 4$ & $12 \cdot 3$ \\
\hline 2 & $8 \cdot 02$ & 0.40 & $104 \cdot 6$ & 25.0 & 12.95 & $I \cdot I I$ & $46 \cdot 9$ & $I x \cdot 2$ \\
\hline 3 & 10.59 & 0.51 & $9 \mathrm{I} \cdot 2$ & $2 \pi \cdot 8$ & 13.95 & $1 \cdot 32$ & $50 \cdot 5$ & $12 \cdot I$ \\
\hline 4 & $12 \cdot 17$ & 0.63 & IOI' 3 & $24 \cdot 2$ & I $7 \cdot 86$ & 0.88 & 647 & 15.8 \\
\hline 5 & $14 \cdot 18$ & 0.67 & I I $8+1$ & $28 \cdot 2$ & 19.05 & $x \cdot 32$ & $69^{\circ}$ & 16.5 \\
\hline 6 & 14.87 & 0.69 & $123 \cdot 8$ & $29 \cdot 6$ & $22 \cdot 73$ & $2 \cdot 20$ & $82 \cdot 4$ & 19.61 \\
\hline 7 & $\mathrm{r}_{5} \cdot 68$ & 0.74 & $130^{\circ} 5$ & $28 \cdot 4$ & $26 \cdot 14$ & I.95 & 94.8 & $22 \cdot 6$ \\
\hline 8 & $16 \cdot 17$ & 0.95 & $134 \cdot 6$ & $32 \cdot 2$ & $29 \cdot 27$ & $2 \cdot 50$ & $106 \cdot 1$ & $25 \% 4$ \\
\hline
\end{tabular}

Hand-rearing. Although rabbit pups are normally suckled only once each day (Venge, 1963), because of the considerably lower energy value of the artificial diet compared with rabbit milk, all the hand-reared animals were fed twice each day, at 09.00 and 17.00 hours. The pups readily took the milk from a small bottle fitted with a latex teat and the mean daily intakes of eleven pups during their first $8 \mathrm{~d}$ of suckling are given in Table 3 . The values can be compared with those reported by Venge ( 1963 ) for the daily intake of Blue Vienna rabbit pups.

Sampling procedures. The stomachs of the adult and doe-reared rabbits were removed and separated into walls and contents, as described by Henschel (1973). The stomachs from hand-reared rabbits were kept intact since separation was difficult owing to the softness of the contents. The stomach samples were weighed and then stored at $-20^{\circ}$.

The pancreases and small intestines were carefully removed, weighed and stored at $-20^{\circ}$. No separation of the small intestines into walls and contents, or division into duodenum, jejunum and ileum was attempted.

Determination of gastric protease activity. The whole stomachs, separated walls and stomach contents were homogenized in, and appropriately diluted with, ice-cold $0.0 \mathrm{I} \mathrm{M}-\mathrm{HCl}$. Gastric protease activity was determined with casein as substrate, as described by Henschel (1973). To allow comparison with the results from the handreared rabbits the results for each pair of stomach walls and contents of the adult and of the doe-suckled rabbits were combined to give the activity/g whole stomach.

Determination of pancreatic protease concentration. Trypsin and $\alpha$-chymotrypsin each gave a flat peak of optimal activity between $\mathrm{pH} 7 \cdot 0$ and $9^{\circ} 0$ with a casein substrate and could not be separated on the basis of their $\mathrm{pH}$ optima. They were therefore assayed separately with the chromogenic substrates $N$-benzoyl L-arginine $p$-nitroanilide for trypsin (Erlanger, Kokowsky \& Cohen, 196r) and $N$-benzoyl L-tyrosine $p$-nitroanilide for chymotrypsin. Both substrates were supplied by Sigma (London) Chemical Co. Ltd, London SW6. The working substrates were prepared by dissolving each separately as a $0.05 \mathrm{M}$-solution in dimethyl sulphoxide and diluting $5 \mathrm{ml}$ of this 


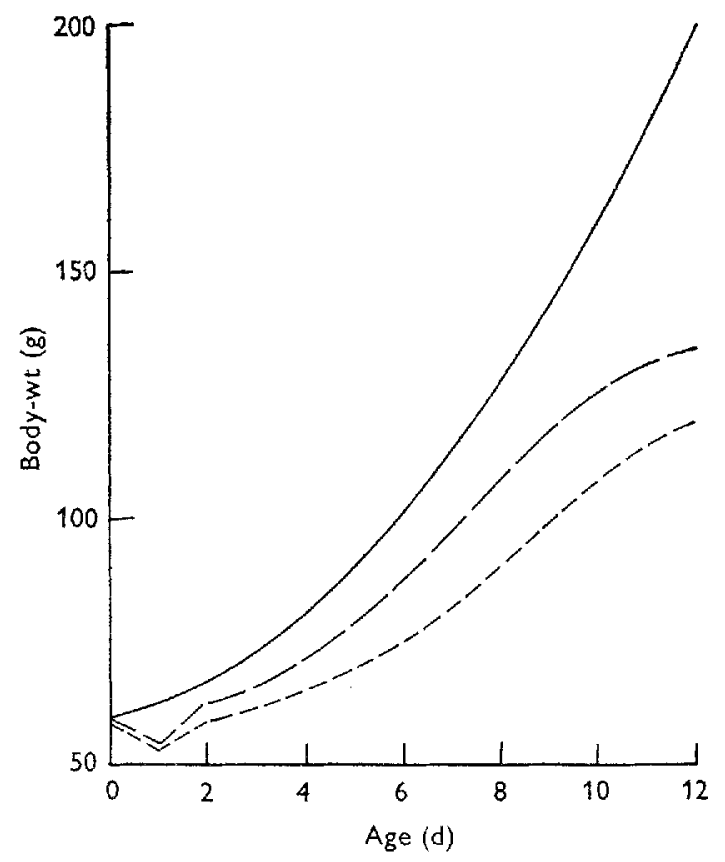

Fig. I. Mean growth rate of eight doe-suckled rabbits (-) compared with that of eleven rabbits hand-reared on the standard diet based on cow's milk (---) and twelve given the standard diet predigested with trypsin and $\alpha$-chymotrypsin (- ).

Table 4. Effect of predigestion with trypsin and $\alpha$-chymotrypsin of the diet based on cow's milk on survival of rabbits during the first $12 \mathrm{~d}$ of life

\begin{tabular}{lccc}
\multicolumn{1}{c}{ Diet } & $\begin{array}{c}\text { No. of } \\
\text { rabbits }\end{array}$ & $\begin{array}{c}\text { No. of } \\
\text { deaths }\end{array}$ & $\begin{array}{c}\text { Survival } \\
(\%)\end{array}$ \\
Predigested & 39 & 9 & 77 \\
Control & 36 & 20 & 44
\end{tabular}

with $195 \mathrm{ml}$ of tris-Ca buffer (0.05 M-(tris)(hydroxymethyl)methylamine and $0.02 \mathrm{M}$ $\mathrm{CaCl}_{2}$, adjusted to $\mathrm{pH} 8 \cdot 2$ with $5 \mathrm{M}-\mathrm{HCl}$ ).

The pancreases from each age group of doe-suckled and hand-reared rabbits were homogenized with ninety-nine times their weight of tris-Ca buffer. A volume of $5 \mathrm{ml}$ of each homogenate was removed and incubated for $30 \mathrm{~min}$ at $37^{\circ}$ with $5 \mathrm{mg}$ enterokinase, extracted from fresh pig duodenal contents by the method of Kunitz (1939). For chymotrypsin determination, the homogenates were used undiluted; for trypsin, I $\mathrm{ml}$ of each was diluted to $5^{0-100 ~} \mathrm{ml}$ with tris-Ca buffer.

The individual small intestines were homogenized with nine times their weight of tris-Ca buffer. The undiluted homogenate was used for both trypsin and chymotrypsin measurement without preliminary activation with enterokinase.

Three $\mathrm{I} \mathrm{ml}$ volumes of each sample were pipetted into test-tubes in a water-bath at $37^{\circ}$. To one of the three, the blank, was added I $\mathrm{ml}$ aqueous acetic acid containing $300 \mathrm{ml}$ glacial acetic acid/1. All tubes then received $4 \mathrm{ml}$ of the appropriate substrate. Concurrently, a range of standard solutions containing $0-20 \mu \mathrm{g}$ crystalline trypsin 

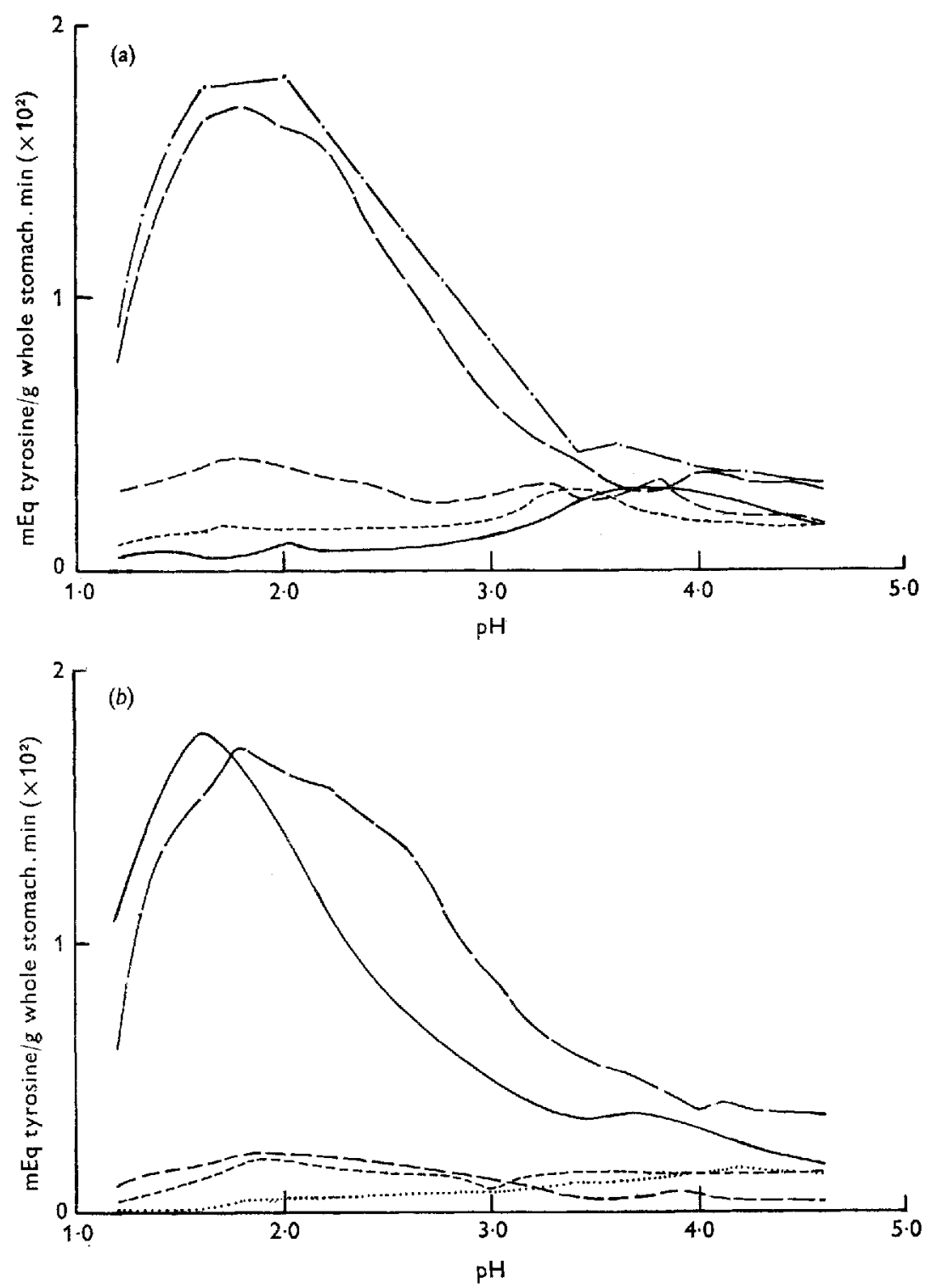

Fig. 2. Mean pH-activity curves for the whole stomachs of groups of infant and adult rabbits. Mean values for $(a)$ groups of seven doe-suckled rabbits at birth $\left(-{ }_{-}\right)$, of six at I (----), $2(-)$ and $3(--)$ weeks of age and of eight at 4 weeks $(-\cdot-)$, and $(b)$ groups of four handreared rabbits at $3 \mathrm{~d}(\ldots \ldots)$, I $(---), 2(-)$ and $3(--)$ weeks of age, and two adults $(-)$.

or $\alpha$-chymotrypsin/ml was incubated also with $4 \mathrm{ml}$ substrate/tube. At the end of $\mathrm{I} \mathrm{h}$, digestion was stopped by the addition of $\mathrm{r} \mathrm{ml}$ of the aqueous acetic acid. The blanks and digestion mixtures were filtered through Whatman no. 542 papers, and the increase in extinction developed during incubation was read at $49 \mathrm{rm}$ on a Unicam $\mathrm{SP}_{5} 00$ spectrophotometer. Results were calculated as $\mu \mathrm{g}$ chymotrypsin or $\mathrm{mg}$ trypsin/g pancreas and as $\mu \mathrm{g}$ chymotrypsin or trypsin/g small intestine. 


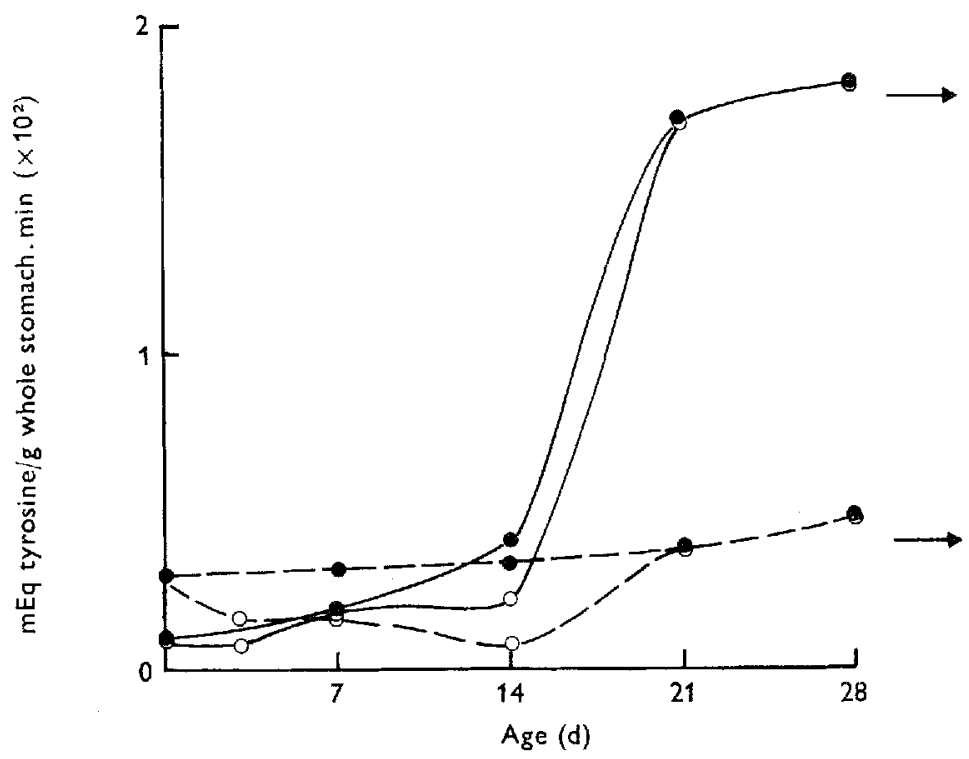

Fig. 3. Mean change with age in gastric proteolytic activity at $\mathrm{pH} 1 \cdot 6-2 \cdot 0(-)$ and $3 \cdot 5^{-}$ $4 \circ(-)$ in groups of six to eight doe-suckled $(0)$ and four hand-reared $(O)$ rabbits, compared with two adults (-十).
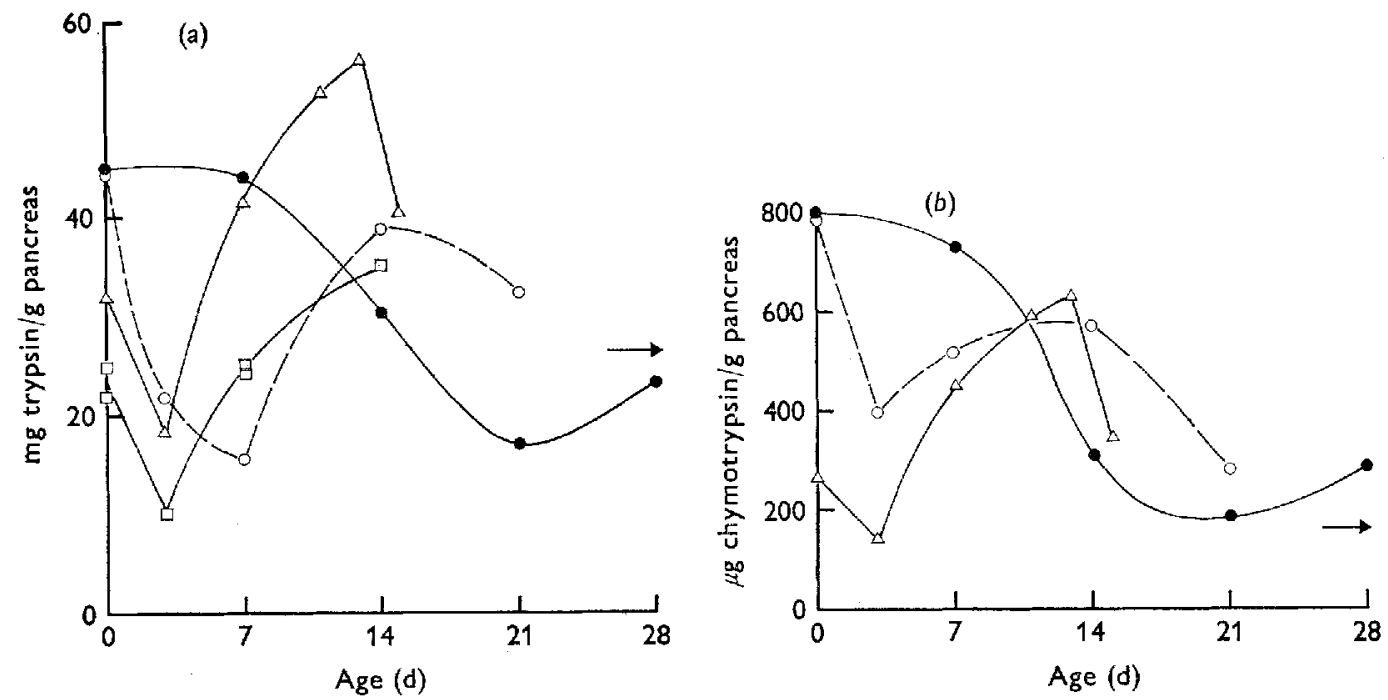

Fig. 4. Change with age in concentration of trypsin (a) and chymotrypsin $(b)$ in pooled pancreases of groups of four hand-reared, conventional rabbits $(--\longrightarrow)$, six to eight doesuckled rabbits $(-)$, and in individual germ-free rabbits from single litters $(\Delta-\Delta$, $\square-\square)$ compared with the mean value in two adults ( $\longrightarrow$ ). 


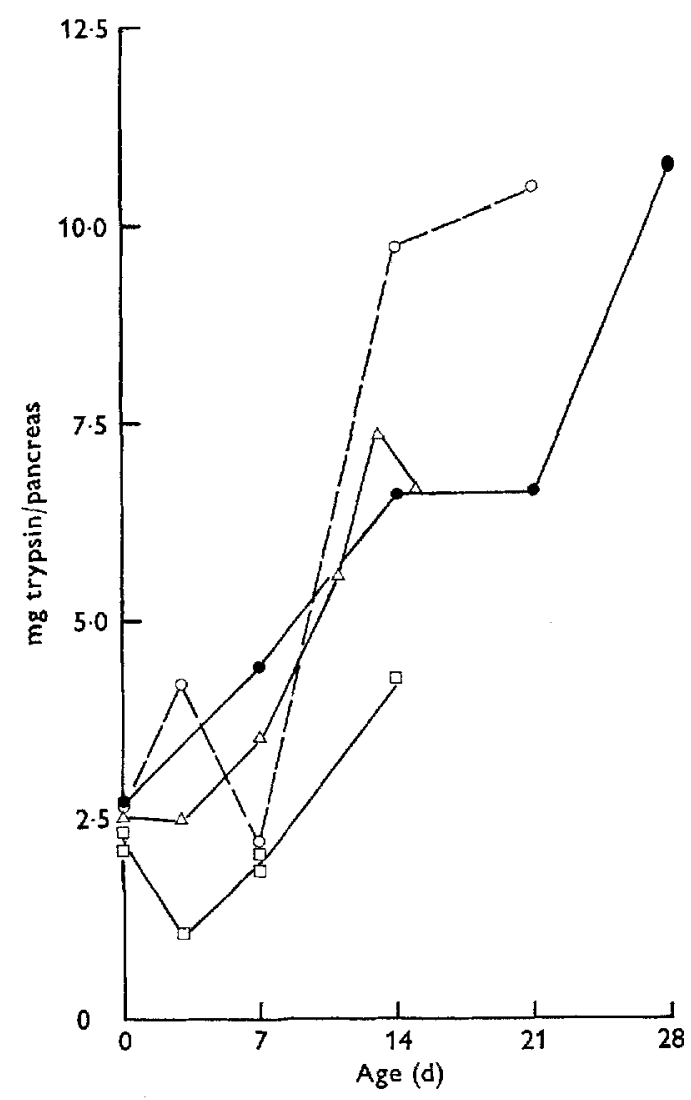

Fig. 5. Change with age in pancreatic trypsin content in doe-suckled ( $)$, and in hand-reared conventional $(0)$ and germ-free $(\Delta, \square)$ rabbits. (Individual members of four different litters.)

\section{RESULTS}

Feeding with predigested diet. The growth of doe-suckled pups and of pups receiving the standard and the predigested diet are shown in Fig. I. Predigested diet led to a marked improvement in the proportion of rabbits that survived to $12 \mathrm{~d}$ of age (Table 4). This improvement was reflected to a lesser extent in the mean growth rate (Fig. I), which was intermediate between that of the doe-suckled pups and of the control animals.

Gastric proteases. The mean $\mathrm{pH}$-activity curves for gastric proteolytic activity in each group of doe-suckled and hand-reared rabbits are given in Fig. $2(a)$ and $(b)$ respectively. Fig. 3 shows the mean changes with age in activity at the $\mathrm{pH}$ optima.

The level of activity at $\mathrm{pH}_{3.5-4.0}$ in both groups remained low, whereas that of pepsin at $\mathrm{pH} \mathrm{I}_{\mathrm{r}} \cdot 6-2 \cdot 0$ increased slowly to 2 weeks of age, then increased rapidly during the 3 rd week to reach a level similar to that found in the adult rabbit stomach (Fig. $2 b$ ).

Pancreatic proteases. The development of chymotrypsin (Fig. $4^{b}$ ) paralleled that of trypsin (Fig. $4 a$ ) in the pancreases of both doe-suckled and hand-reared rabbits, but at a very much lower level. However, the patterns of development varied con- 


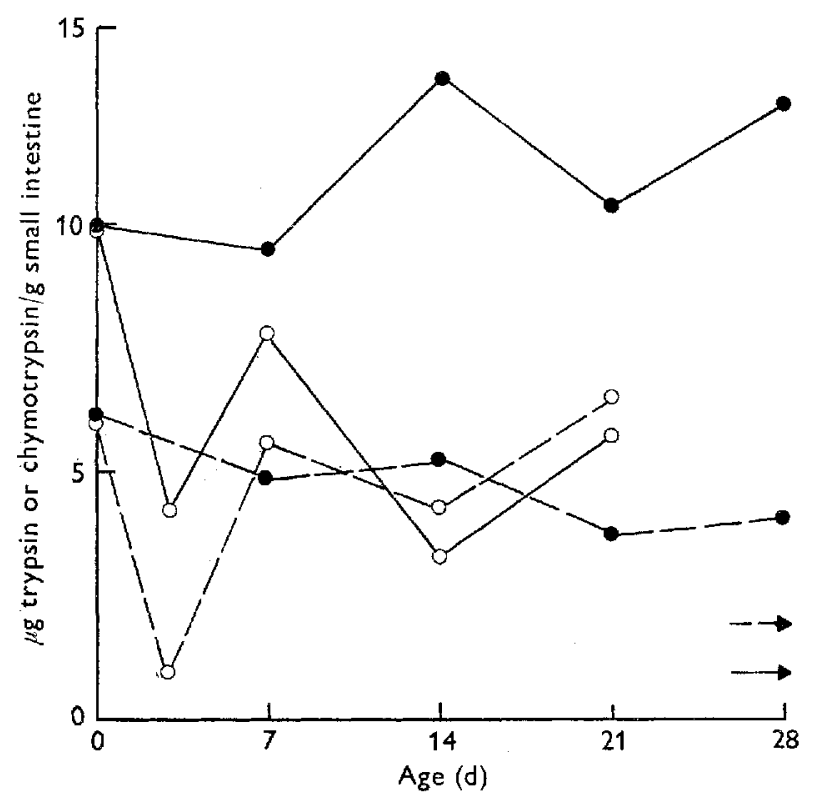

Fig. 6. Mean change with age in the concentration of trypsin $(--)$ and chymotrypsin $(---)$ in the small intestines of groups of four hand-reared (O) and six to eight doe-suckled (O) rabbits during the first $3-4$ weeks of life, compared with the mean levels of trypsin (- and chymotrypsin (- $\rightarrow$ ) in the small intestines of two adults.

siderably between the two groups. In the doe-suckled animals the concentration of both enzymes was highest during the Ist week of life, falling steadily after that to a minimum at 3 weeks of age; at 4 weeks the values were close to those found in the pancreases of the adult rabbits. In the conventional and germ-free hand-reared rabbits the concentration of both enzymes fell sharply during the ist week post partum before recovering to a value slightly higher than that of the doe-suckled pups.

The differences in proteolytic activity between doe- and hand-reared pups were reflected in the mean total content of protease activity in the pancreases shown in Fig. 5 for trypsin only. The mean value at birth $(2 \cdot 1-2 \cdot 7 \mathrm{mg})$ was similar in all groups and all environments. In the doe-reared rabbits, as the pancreas weight increased with age, so there was a corresponding increase in total trypsin up to 2 weeks of age. During the $3^{\text {rd week }}$ of life the weight increase was counterbalanced by the decrease in trypsin concentration, but when this rose in the 4 th week it caused a further increase in total trypsin. In hand-reared pups, the total trypsin content of the pancreas was generally below that of doe-suckled animals during the first $7 \mathrm{~d}$ of life.

The small intestines contained only small amounts of proteolytic activity (Fig. 6), and a marked fall in the concentration of both enzymes in hand-reared rabbits occurred at the age of $3 \mathrm{~d}$. It is of interest that the concentration of chymotrypsin was much closer to that of trypsin in the intestine than in the pancreas. 


\section{DISCUSSION}

It is evident from Table 3 that the mean daily energy intakes of the hand-reared rabbits was below that expected of doe-suckled pups. The extent to which the lower intake of nutrients contributed to the high death rate observed among hand-reared rabbits during the first $\mathrm{r} 2 \mathrm{~d}$ after birth cannot be assessed, though it may have contributed to the steady decline in condition that was observed before death.

The main purpose of this investigation was to study the development of protein digestion in the rabbit pup and certain conclusions can be drawn.

Pepsin, the main gastric enzyme, was slow to develop. The level of activity at $\mathrm{pH} \mathrm{r} \cdot 6-2 \cdot 0$ remained low in both the doe-suckled and hand-reared rabbits until the age of 2 weeks, when a rapid increase took place. Concurrently, a fall in the concentration of the pancreatic enzymes occurred in the doe-suckled pups, which presumably shifted the main site of proteolysis from the small intestine to the stomach, but probably maintained a fairly even general level of activity. However, in the handreared rabbits the pancreatic protease level fell rapidly after birth, when proteolytic activity in the stomach was also low. It is possible that the resulting low level of total proteolytic activity in the gut was insufficient to allow protein digestion to proceed fast enough to support life. This would account to a large extent for the abnormally high death rate observed among hand-reared rabbits during the first $12 \mathrm{~d}$ after birth.

Evidence to support this hypothesis was obtained by pretreatment of the diet with the deficient enzymes. The survival rate during the first $12 \mathrm{~d}$ improved markedly and there was an improvement also in the growth rate.

The cause of the early fall in pancreatic protease concentration in hand-reared rabbits is, as yet, not clear. It is possible that the stress of constant handling depressed the synthesis of the pancreatic enzymes, possibly as a result of changes in the balance of the adrenocorticosteroid hormones. Such an effect might be aggravated by some dietary deficiency, perhaps of readily utilizable carbohydrate, if the comparatively large amount of lactose in the diet based on cow's milk were not at first adequately digested. Both these possibilities require further investigation. It would be of interest also to compare the output of the other exocrine pancreatic enzymes in doe- and handreared pups during the first 2 weeks of life.

I should like to express my gratitude to Dr M. E. Coates for her help and advice. Thanks are due also to Mr E. V. Ruby and Mr D. A. F. Miles for the supply and maintenance of the rabbits.

\section{REFERENCES}

Coates, M. E., Gregory, M. E. \& Thompson, S. Y. (1964). Br. F. Nutr. 18, 583.

Coates, M. E. \& O'Donoghue, P. N. (1967). Nature, Lond. 2r3, 307.

Cowie, A. T. (1969). F. Endocr. 44, 437.

Erlanger, B. F., Kokowsky, N. \& Cohen, W. (1961). Archs Biochem. Biophys. 95, 27 r.

Henschel, M. J. ( 1973). Br. Y. Nutr. 30, 285.

Kunitz, M. (1939). F. gen. Physiol. 22, 447.

Venge, O. (1963). Anim. Behav. II, 500. 